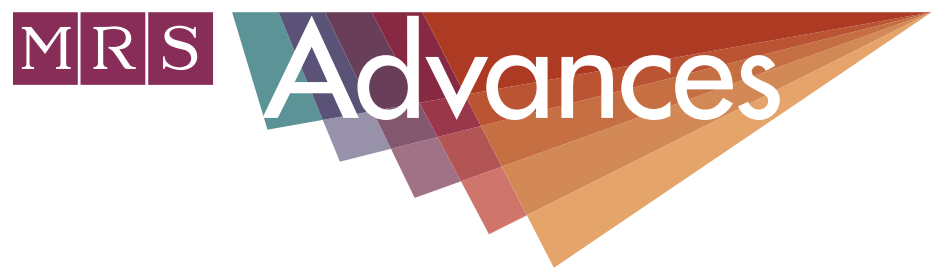

\title{
A heptamethine cyanine dye suitable as antenna in biohybrids based on bacterial photosynthetic reaction center
}

\author{
Roberta Ragni ${ }^{1}$, Gabriella Leone ${ }^{1}$, Simona la Gatta ${ }^{1,2}$, Giorgio Rizzo ${ }^{1}$, Marco Lo Presti ${ }^{1}$, \\ Vincenzo De Leo ${ }^{1}$, Francesco Milano, ${ }^{3, \#}$, Massimo Trotta ${ }^{2, *}$ and G. M. Farinola ${ }^{1, *}$
}

\begin{abstract}
${ }^{1}$ Dipartimento di Chimica, Università degli Studi di Bari “Aldo Moro”, via Orabona 4, I-70126 Bari ${ }^{2}$ Istituto per i Processi Chimico-Fisici CNR-IPCF, Dipartimento di Chimica, via Orabona 4, I-70126 Bari; ${ }^{3}$ CNR-ISPA, Institute of Sciences of Food Production, Lecce Unit, Via Prov.le Monteroni, 73100 Lecce, Italy. " Permanent address: Istituto per i Processi Chimico-Fisici CNR-IPCF. * Authors to whom correspondence should be addressed
\end{abstract}

ABSTRACT:

Sunlight is the most environmental friendly energy source available on Earth; many efforts devoted to design artificial photoconversion systems are ongoing, nevertheless they are still expensive and poorly efficient. Photoconversion devices made with organic-biological hybrids, or biohybrids, based on the photosynthetic reaction center (RC) have been introduced. In these systems, the photoenzyme is garnished with artificial antennas to enhance the photoactivity of the RC. Here we present a newly synthesized heptamethine cyanine dye that fulfills requisites to act as efficient $R C$ light harvesting antenna.

\section{INTRODUCTION:}

Sun is the most abundant and cheap energy source for the Earth and it will irradiate our planet for roughly other five billions of years. Environmental and economic factors are slowly shifting energy supply from the traditional fossil fuels to inorganic or organic solar photoconverters that have been inspired, designed and engineered to mimic the photosynthetic process performed by plants, algae and photosynthetic bacteria[1].

The design of artificial solar photoconverters mimicking or exploiting the actual molecular machineries that drive the photosynthetic process, the so-called reaction centers (RCs) is a long-standing goal in the field of artificial photosynthesis. The RCs are transmembrane enzymes that function as photochemical core of any eukaryotic or 
prokaryotic photosynthetic organism and are responsible for the highly efficient conversion of sunlight into chemical energy[2].

Among the RCs, one of the simplest and in deep investigated can be obtained from the purple non-sulphur anoxygenic photosynthetic bacterium Rhodobacter (R.) sphaeroides that is used as model system in photosynthesis since early ' $70 \mathrm{~s}$ [3].

Briefly, the RC from the purple non-sulphur anoxygenic photosynthetic bacterium $R$. sphaeroides is a transmembrane enzyme composed by three protein subunits that form the scaffolding for several cofactors. The cofactors are organized along two almost symmetrical branches, called A and B. Two partly overlapping bacteriochlorophyll molecules form the first cofactor found on the periplasmic side. This species, called dimer or $\mathrm{D}$, is responsible for the absorption of the photon and the formation of the excited state $\mathrm{D}^{*}$. The electron sitting in the excited state is shuttled toward other cofactors leaving the cation $\mathrm{D}^{+}$behind. The electron moves toward the other pigment sitting along the $\mathrm{A}$ branch, namely a monomeric bacteriochlorophyll $\mathrm{BChl}_{\mathrm{A}}$, a bacteriopheophytin $\mathrm{BPhe}_{\mathrm{A}}$ and, eventually, a ubiquinone-10 $\mathrm{Q}_{\mathrm{A}}$ molecule hence reaching the cytoplasmic side of the protein. A second loosely bound quinone sitting on the $\mathrm{B}$ branch $\left(\mathrm{Q}_{\mathrm{B}}\right)$ receives the electron forming the final charge-separated state $\mathrm{D}^{+} \mathrm{Q}_{\mathrm{B}}{ }^{-} \cdot \mathrm{D}^{+} \mathrm{Q}_{\mathrm{B}}{ }^{-}$ has a lifetime of roughly $1 \mathrm{~s}$ after which the charges recombine returning the protein in its neutral state. $\mathrm{Q}_{\mathrm{B}}$ can be easily removed[4] and the charge-separated state $\mathrm{D}^{+} \mathrm{Q}_{\mathrm{A}}{ }^{-}$has a lifetime of roughly $100 \mathrm{~ms}[5-8]$. The enzyme is well engineered and the yield of conversion is $\sim 98 \%$, i.e. virtually each absorbed photon generates a charge-separated state[9]. The RC in the photosynthetic membrane is associated with two proteins called light harvesting complexes LH1 and LH2, also known as antenna proteins, which improve the ability of harvesting light by increasing the overall optical cross-section of the RC-LH1/LH2 complex. Extracted and isolated from the bacterium, the RC loses the antenna proteins and, although still fully functional, strongly decreases its light harvesting ability[10]. This ability can be restored by chemically conjugating an organic fluorophore to the $\mathrm{RC}$, forming a biohybrid. The concept of a functional biohybrid over performing the pristine protein in producing charge-separated state was firstly demonstrated using an aryleneethynylene fluorophore $\left(\mathrm{AE}_{600}\right)$ as artificial antenna [1114]. A proper artificial antenna should (i) absorb in the visible region, (ii) possess an emission that overlaps the RC absorption for efficient energy transfer, (iii) possess a consistent Stokes shift for avoiding the self-absorption, (iv), have a high quantum yield and $(v)$ have a chemical moiety suitable for $\mathrm{RC}$ anchoring. The biohybrid $\mathrm{AE}_{600}-\mathrm{RC}$ fulfills all the above requisites and produces a fivefold increase in the amount of chargeseparated state compared to that obtained in pristine $\mathrm{RC}$ irradiated with the same number of photons having wavelength coincident with the maximum absorption of the dye. Several other dyes were synthesized according to previously published general procedure[14-20]. These molecules were used as artificial antennas both to a single wavelength[21-24] or under white light[25] and successfully used to enhance the photoactivity of the pristine RC. Some of them have been obtained by organometallic reactions[26, 27]. Nevertheless, the highest photoconversion efficiency achieved thus far in the entire visible spectrum for biohybrid RCs overcomes that of the bare RC by roughly $30 \%$ and such outcome could be further enhanced by suitably selecting other organic light harvesting molecules. To the purpose of developing biohybrids with optimized performances, in the present work, we report the synthesis and preliminary photophysical characterization of a heptamethine cyanine antenna (Hcy-2 in Figure 1) that can be very easily obtained without the use of organometallic reactions from a commercially available precursor IR-780. This molecule possesses high extinction coefficient, emission quantum yield and solubility in aqueous solutions[28] but exhibits a small the Stokes shift, unsuitable for being used as artificial antenna[12]. IR-780 was hence opportunely modified by substituting the chlorine atom with a suitable amine to 
ameliorate the Stokes shift of the molecule. The newly synthetized cyanine shows all the above required requisites and, mixed in solution with the $\mathrm{RC}$, improves the photoactivity of the photosynthetic enzyme.

\section{EXPERIMENTALS:}

\section{Synthesis and characterization of the artificial antenna}

The Hcy-2 synthesis was performed through nucleophilic substitution reaction at the chlorine atom of the IR-780 (CAS number 207399-07-03) with the 8aminoottanoic acid (Figure 1). Structural modification of dyes is an important tool to tune spectroscopic properties[29]. In this case the substitution induces an ipsochromic shift in the absorption and emission peaks and increases the Stokes shift[30, 31], minimizing the self-absorption of emitted photons. The pendant carboxylic functional group is a prerequisite for any subsequent covalent binding to the $\mathrm{RC}$ via its activation with N-hydroxysuccinymide.

In brief, $25 \mathrm{~mL}$ of anhydrous $N, N$-dimethylformamide (DMF) and $0.476 \mathrm{~g}$ (2.99 $\mathrm{mmol}$ ) of 8-aminooctanoic acid were added in a $50 \mathrm{~mL}$ three-necked flask. The reaction was performed under nitrogen flux and magnetic stirring at $80{ }^{\circ} \mathrm{C}$ for $1 \mathrm{~h}$. Then $0.200 \mathrm{~g}$ (29.9 mmol) of commercial cyanine IR-780 were added. Reaction was left overnight. Once mixture was cooled to room temperature, the product was extracted with dichloromethane $(25 \mathrm{~mL})$ in a separatory funnel using water $(5 \times 25 \mathrm{~mL})$ to remove DMF. The organic phase was dried with anhydrous $\mathrm{Na}_{2} \mathrm{SO}_{4}$ and the crude product was obtained, as a blue powder, by filtration and distillation of the solvent at reduced pressure. Hcy-2 was isolated, in $48 \%$ yield, using a CombiFlash $\mathrm{Rf}+$ chromatograph equipped with a $50 \mathrm{~g}$ Gold reverse phase $\mathrm{C}-18$ column and a mixture of water and acetonitrile $(6: 4 \mathrm{v} / \mathrm{v})$ as the mobile phase. ${ }^{1} \mathrm{H}$ - NMR spectrum of Hcy-2 was recorded in dichloromethane-d2 at $500 \mathrm{Mhz}$, using an Agilent Technologies 500/54 Premium Shielded spectrometer. ${ }^{1} \mathrm{H}$ NMR $\left(500 \mathrm{MHz}, \mathrm{CD}_{2} \mathrm{Cl}_{2}\right)$ : $7.71 \mathrm{ppm}(\mathrm{d}, \mathrm{J}=12.8 \mathrm{~Hz}, 2 \mathrm{H})$, $7.31 \mathrm{ppm}(\mathrm{dd}, \mathrm{J}=19.2 \mathrm{~Hz}, 7.6 \mathrm{~Hz}, 4 \mathrm{H}), 7.08 \mathrm{ppm}(\mathrm{t}, \mathrm{J}=7.5 \mathrm{~Hz}, 2 \mathrm{H}), 6.91 \mathrm{ppm}(\mathrm{d}, \mathrm{J}=7.9$ $\mathrm{Hz}, 2 \mathrm{H}), 5.68 \mathrm{ppm}(\mathrm{d}, \mathrm{J}=12.3 \mathrm{~Hz}, 2 \mathrm{H}), 3.86-3.75 \mathrm{ppm}(\mathrm{m}, 5 \mathrm{H}), 2.53 \mathrm{ppm}(\mathrm{t}, \mathrm{J}=6.3 \mathrm{~Hz}$, $4 \mathrm{H}), 2.39 \mathrm{ppm}(\mathrm{t}, \mathrm{J}=7.2 \mathrm{~Hz}, 2 \mathrm{H}), 1.84 \mathrm{ppm}(\mathrm{m}, 10 \mathrm{H}), 1.69 \mathrm{ppm}(\mathrm{s}, 12 \mathrm{H}), 1.45 \mathrm{ppm}(\mathrm{s}$, $6 \mathrm{H}), 1.29 \mathrm{ppm}(\mathrm{s}, 2 \mathrm{H}), 1.05 \mathrm{ppm}(\mathrm{t}, \mathrm{J}=7.4 \mathrm{~Hz}, 6 \mathrm{H})$.

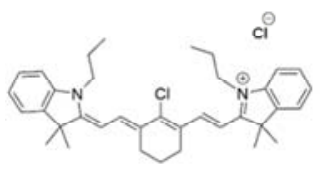

IR-780

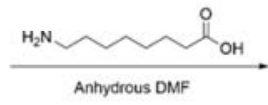

Anhydrous DMF

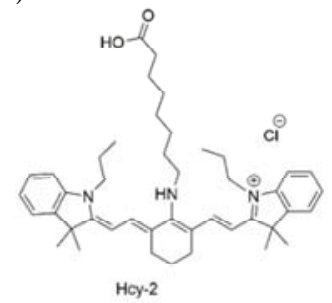

Figure 1. Synthesis of Hcy-2: 2-((E)-2-((E)-2-((7-carboxyheptyl)amino)-3-((Z)-2-(3,3-dimethyl-1-propylindolin-2ylidene)ethylidene)cyclohex-1-en-1-yl)vinyl)-3,3-dimethyl-1-propyl-3H-indol-1-ium chloride.

\section{$\underline{\text { Rhodobacter sphaeroides culture and reaction center purification }}$}

The carotenoidless strain Rhodobacter sphaeroides R26 was grown under intense illumination in absence of oxygen according to previously published protocols[32, 33]. Reaction Centers were isolated as previously described[34-36]. Protein purity was checked using the ratio of the absorbance at 280 and $802 \mathrm{~nm}$ (A280/A802) 
which was kept below 1.3. The ratio between the absorbance at 760 and $865 \mathrm{~nm}$ (A760/A865) was used as test for protein integrity and kept equal to or lower than 1.

\section{RESULTS AND DISCUSSION:}

\section{$\underline{\text { RC-Artificial antenna system }}$}

Hcy-2 absorbance (red) and emission (blue) spectra are presented in Figure 2A together with the absorption spectrum of the RC (grey). In particular, RC main absorbances are related to bacteriopheophytins (peak centered at $765 \mathrm{~nm}$ ), monomeric (peak centered at $800 \mathrm{~nm}$ ) and dimeric (peak centered at $860 \mathrm{~nm}$ ) bacteriochlorophylls, respectively. Absorption and emission maxima of the artificial antenna fall at $633 \mathrm{~nm}$ (see Figure 2B for extinction coefficient) and $745 \mathrm{~nm}$ respectively, resulting in a Stokes shift of $112 \mathrm{~nm}$. The Hcy-2 absorption band partially overlaps with the $\mathrm{Q}_{\mathrm{y}}$ absorption peak of the enzyme at $605 \mathrm{~nm}$. At $650 \mathrm{~nm}$ the contribution the $\mathrm{Q}_{\mathrm{y}}$ peak is negligible and this wavelength can be used to selectively excite Hcy-2. Oppositely, the emission peak of Hcy-2 fully overlaps with the intense absorption peak of the photosynthetic protein that is eventually prone to use it to drive its photochemistry. These conditions are compulsory for any fluorescent dye to function as efficient antenna.
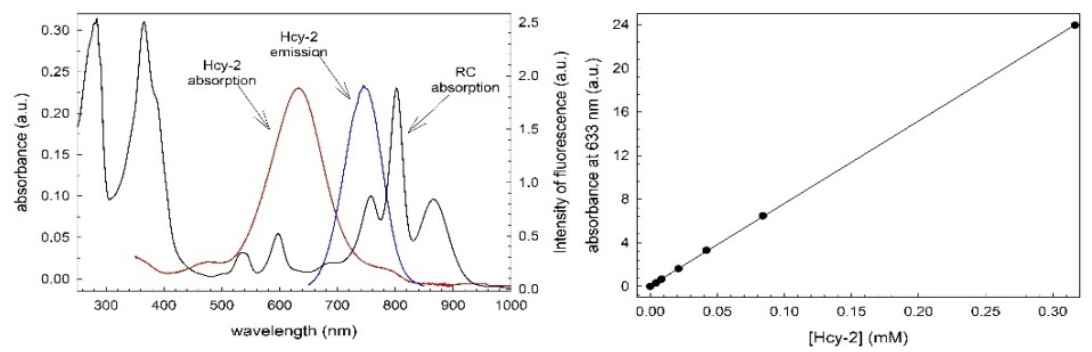

Figure 2. (A) Absorption spectra of Hcy-2 (red) and RC (grey) overlapped with emission spectra (blue) of Hcy-2; (B) Calculation of the molar extinction coefficient of Hcy-2. All spectra were recorded in Triton X-100 $(0.03 \% \mathrm{v} / \mathrm{v})$, Tris- $\mathrm{HCl}$ $20 \mathrm{mM}$ and EDTA $1 \mathrm{mM}$ or $\mathrm{T}_{0.03} \mathrm{~T}_{20} \mathrm{E}_{1} \cdot \mathrm{pH}=8.5, \mathrm{~T}=25^{\circ} \mathrm{C}$. The extension coefficient was found $\varepsilon=75500 \pm 200 \mathrm{M}^{-1} \mathrm{~cm}^{-1}$ $\left(\mathrm{R}^{2}=0.992\right)$.

The absorbance spectrum of a solution containing the RC and Hcy-2 in a 1:5 ratio in $\mathrm{T}_{0.03} \mathrm{~T}_{20} \mathrm{E}_{1}$ buffer is shown in Figure 3 together with the spectrum of the pristine $\mathrm{RC}$ as comparison.

The enhancing effect of the free Hcy-2 on the photoactivity of the $\mathrm{RC}$ was evaluated by irradiating the solution under two relevant conditions: a) at $650 \mathrm{~nm}$, in presence of a strong Hcy-2 absorption and a minimum RC absorption; b) at $800 \mathrm{~nm}$ matching the maximum absorption of the RC and the lack of absorption of Hcy-2.

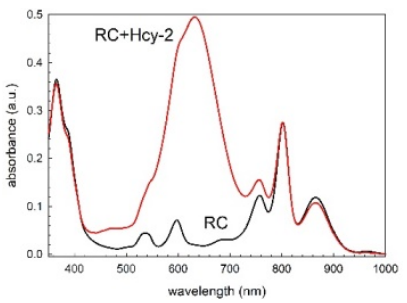


The changes at $865 \mathrm{~nm}$, diagnostic of the formation of the charge-separated state, were recorded, converted in the actual concentration of charge-separated state and the results are summarized in Figure 4. The noteworthy results indicated that Hcy-2 does effectively function as antenna, transferring the harvested light to the $\mathrm{RC}$ and increasing the yield of the charge-separated state formation by $45 \pm 2 \%$. Oppositely, when the solution is irradiated at the maximum absorption of the $\mathrm{RC}$, were no contribution from Hcy-2 is present, the activity of the protein does not change, indicating that the effect is exclusively attributable to the optical properties of the antenna.

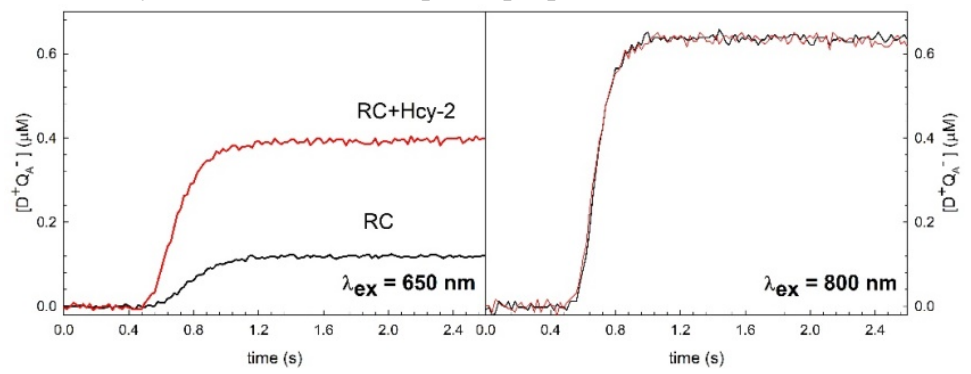

Figure 4. RC-Hcy-2 1:5 (red) and sole RC (grey) activity measurements by monitoring the charge separated state exciting a 650 and $800 \mathrm{~nm}$.

\section{CONCLUSIONS:}

A molecule belonging to the class of cyanines, HCy-2, was synthesized and tested in solution as potential artificial antenna for the bacterial photosynthetic RC. The spectroscopic and photophysical features of $\mathrm{HCy}-2$ make this molecule very attractive for biohybrids based on photosynthetic proteins, with an improvement of $45 \pm 2 \%$ in the yield of the charge-separated state formation.

\section{ACKNOWLEDGMENTS:}

This work was financed by Apulia Region funded Project "FONTANAPULIA - FOtocatalizzatori NanosTrutturati e rAdiazioNe UV per un'Acqua più PULItA" Project $n$. WOBV6K5) and by the European Commission through the EU FET-Open project 800926 - HyPhOE (Hybrid Electronics based on Photosynthetic Organisms).

\section{References:}

[2] P. Maróti and M. Trotta, in CRC Handbook of Organic Photochemistry and Photobiology, Third Edition - Two Volume Set, edited by A. Griesbeck, M. Oelgemöller and F. Ghetti (CRC Press, 2012), pp. 1289-1324.

[3] G. Feher, Photochem. Photobiol. 14 (3), 373-387 (1971).

[4] M. Y. Okamura, R. A. Isaacson and G. Feher, Proc. Natl. Acad. Sci. U. S. A. 72 (9), $3491-$ 3495 (1975).

[5] G. Feher, J. P. Allen, M. Y. Okamura and D. C. Rees, Nature 339, 111-116 (1989). 
[6] J. P. Allen, G. Feher, T. O. Yeates, H. Komiya and D. C. Rees, Proceedings of the National Academy of Sciences 85 (22), 8487-8491 (1988).

[7] J. P. Allen, G. Feher, T. O. Yeates, H. Komiya and D. C. Rees, Proceedings of the National Academy of Sciences 84 (16), 5730-5734 (1987).

[8] F. Milano, R. R. Tangorra, A. Agostiano, L. Giotta, V. De Leo, F. Ciriaco and M. Trotta, MRS Advances 3 (27), 1497-1507 (2018).

[9] C. A. Wraight and R. K. Clayton, Biochim. Biophys. Acta 333 (2), 246-260 (1974).

[10] F. Milano, F. Italiano, A. Agostiano and M. Trotta, Photosynth. Res. 100 (2), 107-112 (2009).

[11] B. D. Belviso, R. R. Tangorra, F. Milano, O. Hassan Omar, S. la Gatta, R. Ragni, A.

Agostiano, G. M. Farinola, R. Caliandro and M. Trotta, MRS Advances FirstView, 1-12 (2016).

[12] F. Milano, R. R. Tangorra, O. Hassan Omar, R. Ragni, A. Operamolla, A. Agostiano, G. M.

Farinola and M. Trotta, Angew. Chem. 124 (44), 11181-11185 (2012).

[13] E. Altamura, F. Milano, R. R. Tangorra, M. Trotta, O. Hassan Omar, P. Stano and F. Mavelli, Proc. Natl. Acad. Sci. USA 114 (15), 3837-3842 (2017).

[14] R. Ancora, F. Babudri, Gianluca M. Farinola, F. Naso and R. Ragni, Eur. J. Org. Chem. 2002 (24), 4127-4130 (2002).

[15] A. Operamolla, R. Ragni, O. H. Omar, G. Iacobellis, A. Cardone, F. Babudri and G. M.

Farinola, Current Organic Synthesis 9 (6), 764-778 (2012).

[16] A. Punzi, D. I. Coppi, S. Matera, M. A. M. Capozzi, A. Operamolla, R. Ragni, F. Babudri and G. M. Farinole, Org. Lett. 19 (18), 4754-4757 (2017).

[17] A. Punzi, M. A. M. Capozzi, S. Di Noja, R. Ragni, N. Zappimbulso and G. M. Farinola, J. Org. Chem. 83 (16), 9312-9321 (2018).

[18] R. Ragni, S. Cicco, D. Vona, G. Leone and G. M. Farinola, J. Mater. Res. 32 (2), 279-291

(2017).

[19] F. Babudri, D. De Palma, G. M. Farinola, R. Ragni and F. Naso, Synthesis-Stuttgart (8), 1227$1232(2008)$.

[20] F. Babudri, A. Cardone, C. T. Cioffi, G. M. Farinola, F. Naso and R. Ragni, SynthesisStuttgart (8), 1325-1332 (2006).

[21] R. R. Tangorra, A. Antonucci, F. Milano, S. la Gatta, G. M. Farinola, A. Agostiano, R. Ragni and M. Trotta, in Handbook of Photosynthesis, Third Edition, edited by M. Pessarakli (CRC Press, USA, 2016), pp. 201-220.

[22] S. la Gatta, O. Hassan Omar, A. Agostiano, F. Milano, R. R. Tangorra, A. Operamolla, C. Chiorboli, R. Argazzi, M. Natali, M. Trotta, G. M. Farinola and R. Ragni, MRS Advances 1 (7), 495-500 (2016).

[23] R. R. Tangorra, A. Antonucci, F. Milano, S. la Gatta, A. Operamolla, R. Ragni, A. Agostiano, M. Trotta and G. M. Farinola, MRS Proceedings Mrsf14-1722, f05-51 (2015).

[24] R. Ragni, O. Hassan Omar, R. R. Tangorra, F. Milano, D. Vona, A. Operamolla, S. La Gatta, A. Agostiano, M. Trotta and G. M. Farinola, MRS Online Proceedings Library 1689 (2014).

[25] O. Hassan Omar, S. la Gatta, R. R. Tangorra, F. Milano, R. Ragni, A. Operamolla, R. Argazzi, C. Chiorboli, A. Agostiano, M. Trotta and G. M. Farinola, Bioconjug. Chem. 27 (7), 1614-1623 (2016).

[26] F. Babudri, G. M. Farinola, L. C. Lopez, M. G. Martinelli and F. Naso, The Journal of Organic Chemistry 66 (11), 3878-3885 (2001).

[27] G. M. Farinola, V. Fiandanese, L. Mazzone and F. Naso, J. Chem. Soc., Chem. Commun. (24), 2523-2524 (1995).

[28] L. Wang, J. Jin, X. Chen, H.-H. Fan, B. K. F. Li, K.-W. Cheah, N. Ding, S. Ju, W.-T. Wong and C. Li, Org. Biomol. Chem. 10 (28), 5366-5370 (2012).

[29] M. Piacenza, F. Della Sala, G. M. Farinola, C. Martinelli and G. Gigli, The Journal of Physical Chemistry B 112 (10), 2996-3004 (2008).

[30] W. Pham, L. Cassell, A. Gillman, D. Koktysh and J. C. Gore, Chem. Commun. (16), 18951897 (2008).

[31] X. Peng, F. Song, E. Lu, Y. Wang, W. Zhou, J. Fan and Y. Gao, J. Am. Chem. Soc. 127 (12), 4170-4171 (2005).

[32] L. Giotta, A. Agostiano, F. Italiano, F. Milano and M. Trotta, Chemosphere 62 (9), 1490-1499 (2006).

[33] L. Giotta, D. Mastrogiacomo, F. Italiano, F. Milano, A. Agostiano, K. Nagy, L. Valli and M. Trotta, Langmuir 27 (7), 3762-3773 (2011).

[34] A. Agostiano, F. Milano and M. Trotta, Eur. J. Biochem. 262 (2), 358-364 (1999).

[35] M. Trotta, F. Milano, L. Nagy and A. Agostiano, Mater. Sci. Eng. C Biomim. Supramol. Syst. 22 (2), 263-267 (2002).

[36] A. Agostiano, F. Mavelli, F. Milano, L. Giotta, M. Trotta, L. Nagy and P. Maroti,

Bioelectrochemistry 63 (1-2), 125-128 (2004). 